\title{
Encephalitis, Reversible Splenial Lesions, and COVID-19
}

Ensefalit, Reversibl Splenial Lezyon ve COVID-19

(1) Rujittika Mungmunpuntipantip ${ }^{1}$, (1) Viroj Wiwanitkit ${ }^{2}$

${ }_{1}^{1}$ Private Academic Consultant, Bangkok, Thailand

2Dr. DY Patil University, Pune, India

Keywords: Encephalitis, splenium, lesion, COVID-19

Anahtar Kelimeler: Ensefalit, splenium, lezyon, COVID-19

\section{Dear Editor,}

We would like to share our ideas on "Mild Encephalitis with Reversible Splenial Lesions Associated with COVID-19” (1). Demir and Arlı (1) stated the following: "In this case report, the key clinical and radiological features of mild encephalitis/ encephalopathy with reversible splenial lesions were highlighted in an adult patient presented to the emergency department with nausea, vomiting, and unconsciousness and admitted to the neurology clinic due to diffusion restriction in the splenium of corpus callosum". The clinical course in this case is very interesting. The patient can have a complete resolution despite the unproven usefulness of antibiotics. The pathogenesis in this case is unknown. If it is a condition caused by inflammatory reaction or direct viral invasion, recovery should not be expected, and antibiotics should not be used. An important pathological process in COVID-19 is increased blood viscosity (2), which may be a cause of both mild encephalitis and splenic lesions $(3,4)$. When the patient received supportive care, including fluid therapy, the blood viscosity decreased, and the clinical problems showed recovery. Therefore, a key clinical point is the recognition of the problem for accurate diagnosis, and a prompt treatment should include a good fluid replacement therapy.

\section{Ethics}

Informed Consent: Not applicable.

Peer-review: Internally peer-reviewed.

Authorship Contributions

Concept: R.M., V.W., Design: R.M., V.W., Data Collection or Processing: R.M., V.W., Analysis or Interpretation: R.M., V.W., Literature Search: R.M., V.W., Writing: R.M., V.W

Conflict of Interest: No conflict of interest was declared by the authors.

Financial Disclosure: The authors declared that this study received no financial support.

\section{References}

1. Demir E, Arl B. Mild encephalitis with reversible splenial lesion associated with COVID-19. Turk J Neurol 2021;27:327-329.

2. Joob B, Wiwanitkit V. Blood viscosity of COVID-19 patient: a preliminary report. Am J Blood Res 2021;11:93-95.

3. Silvestro M, Tessitore A, De Mase A, et al. A 67-year-old woman with recurrent headache, migratory focal symptoms, and impaired consciousness. Headache 2020;60:2622-2630.

4. Appenzeller P, Leith CP, Foucar K, et al. Cutaneous Waldenstrom macroglobulinemia in transformation. Am J Dermatopathol 1999;21:151155.

Address for Correspondence/Yazışma Adresi: Rujittika Mungmunpuntipantip MD, Private Academic Consultant, Bangkok, Thailand Phone: 2828828222 E-mail: rujittika@gmail.com ORCID: orcid.org/0000-0003-0078-7897

Received/Geliş Tarihi: 05.10.2021 Accepted/Kabul Tarihi: 15.11 .2021

${ }^{\oplus}$ Copyright 2021 by Turkish Neurological Society Turkish Journal of Neurology published by Galenos Publishing House. 